
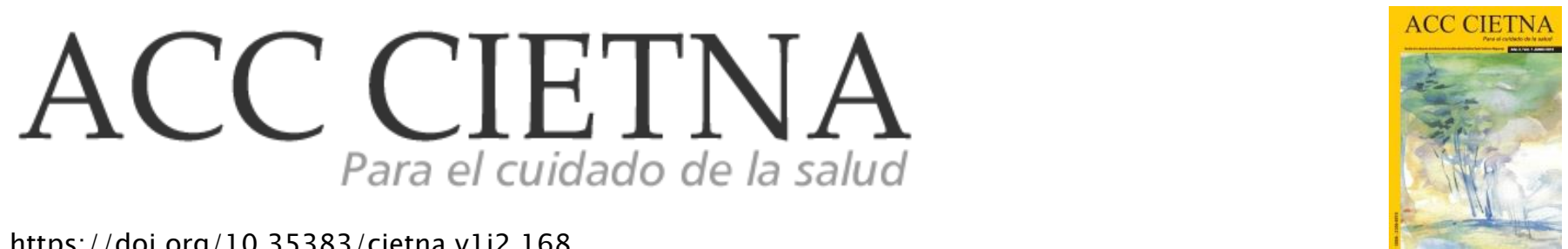

https://doi.org/10.35383/cietna.v1i2.168

EDITORIAL

\title{
Comprometiendo a las enfermeras en la Salud Ambiental Comunitaria... Una cocina a la vez
}

\section{Thompson Lisa $\mathbf{M}^{1}$}

\begin{tabular}{l} 
INFORMACIÓN DEL ARTÍCULO \\
\hline Historia del artículo: \\
Recibido el 3 de junio de 2014 \\
Aceptado el 15 de octubre de 2014
\end{tabular}

Palabras claves:

Salud ambiental

Enfermeras

Entorno

\section{RESUMEN}

Con gran placer escribo este editorial para la II edición de la Revista Peruana de Enfermería Acc Cietna, después de haber tenido el honor de participar en la VII Jornada Internacional de Investigación en Enfermería de la Universidad Católica Santo Toribio de Mogrovejo (USAT), en Chiclayo-Perú, en setiembre de 2013. Estoy muy entusiasmada con los aportes que los profesores y estudiantes de enfermería están haciendo realizan la salud ambiental de las comunidades rurales que dependen de la leña para cocinar, y que se ven perjudicadas por la deforestación. Los estudiantes de enfermería trabajan con las familias plantando árboles en la hermosa y extensa zona del Bosque Seco de Pómac en donde las aves y la fauna abundan. Ellos están creando oportunidades de ecoturismo para que las comunidades rurales puedan mejorar su situación económica más allá de la venta de madera proveniente de los bosques antiguos. Pero quizás lo más importante, es el hecho de estar desarrollando en las familias, prácticas saludables de higiene del hogar, saneamiento básico y campañas de educación ambiental, incluyendo la construcción de estufas eficientes con ventilación a través de una chimenea. Este último paso es vital, no solo para reducir el consumo de combustible, sino para algo más importante: evitar que los niños y las mujeres desarrollen enfermedades asociadas con la exposición a la contaminación del aire en los hogares, incluyendo bajo peso al nacer, neumonía, enfermedad pulmonar obstructiva crónica, enfermedades cardiacas y cataratas.

Después de haber visto el trabajo duro y el increíble entusiasmo entre los profesores y los estudiantes, he reflexionado acerca de una de nuestras primeras fundadoras de la enfermería, Florence Nightingale.

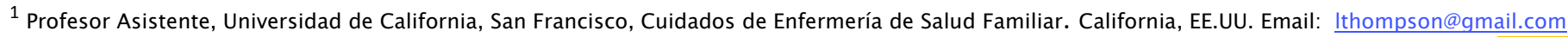


Ella centró sus esfuerzos educativos sobre las modificaciones al entorno, como la ventilación, la calefacción, y la salud de los hogares. Ella abogó por estas modificaciones hace 150 años, incluso antes de que se hiciera evidente para otros científicos que el aire limpio, el agua e incluso algo tan simple, como lavarse las manos, reduce las infecciones (Nightingale, 1860). Hoy en día, las enfermeras siguen en una posición privilegiada para hacer frente a las repercusiones sanitarias de saneamiento de los hogares, incluyendo la exposición a la contaminación del aire de los hogares proveniente de los fogones, que se estima causó 3,5 millones de muertes en todo el mundo en el 2010 (Lim et al., Lancet, 2013). La mayoría de muertes tempranas por contaminación del aire en los hogares se da en mujeres y niños de corta edad, y se estima que 100.000 recién nacidos mueren cada año por esta exposición. La mayoría de estos niños mueren de neumonía, a menudo agravado el cuadro por el bajo peso al nacer y/o prematuridad. Entonces, ¿qué pueden hacer las enfermeras para mejorar la salud de los hogares, incluyendo la reducción de la exposición a la contaminación del aire en los hogares? ¿Por qué son importantes las enfermeras? En primer lugar, las enfermeras visitan a los pacientes "en sus hogares y las comunidades locales...ganando así conocimiento de primera mano....donde las amenazas ambientales (son) a menudo extremas " (Pope et al., 199, pp 2, 13). Las enfermeras también son el mayor grupo de profesionales de la salud en el mundo, y son a menudo el punto inicial y único de contacto para las poblaciones marginadas, pobres con necesidad de atención de salud. Pero ¿dónde están las enfermeras que deben hacer frente a este problema de la contaminación del aire en los hogares y su profunda amenaza a la salud? ¿Han olvidado las enfermeras sus raíces fundadas en la salud ambiental? Muchas enfermeras tienen una formación y educación inadecuadas para reconocer y responder a la enorme amenaza ambiental de la contaminación del aire en los hogares. Abordar este problema va más allá de los programas en las escuelas de enfermería, también requiere de programas de educación continua para las enfermeras que ya se encuentran en la práctica (Pope et al., 1995). No es suficiente capacitar inicialmente estudiantes de enfermería, la formación debe continuar durante toda la carrera. Es imperativo que los educadores de enfermería continúen desarrollando programas educativos para crear conciencia acerca de la higiene y la salud de las familias rurales, incluida la contaminación del aire del hogar por el uso de fogones, que es un problema mundial de salud ambiental. 
ABSTRACT

Keywords:

Enviromental health

Nursing

Environment
It is with great pleasure that I write this editorial for the II edition of the Peruvian Nursing Journal Acc Cietna. Having ha the honor of speaking at the VII International Conference of Nursing Research at the Universidad UNIVERSIDAD CATÓLICA SANTO TORIBIO DE MOGROVEJO (USAT) in Chiclayo, Peru in September 2013, I am extremely enthusiastic about the contributions that nursing faculty and nursing students are making to improve the environmental health of rural communities who depend on wood for cooking and who are impacted by deforestation. Nursing students are working with rural households to replant trees in the beautiful, expansive Dry Forest of Pómac where birds and wildlife abound. They are creating ecotourism opportunities so that rural communities can improve their economic livelihoods beyond the sale of wood from old growth forests. But perhaps more importantly, they are developing household hygiene, sanitation, and environmental education campaigns, including the construction of efficient, vented chimney stoves. This final step is vital, not only to reduce fuel consumption, but more importantly to prevent children and women from developing diseases that are associated with exposure to household air pollution, including low birth weight, pneumonia, chronic obstructive pulmonary disease, cardiac disease and cataracts. Having seen the hard work and incredible enthusiasm among the faculty and students led me to think about one of our earliest founders of nursing, Florence Nightingale. She focused her educational efforts on modifications to the environment such as ventilation, heating, and household health. She advocated for these modifications 150 years ago, even before it became evident to other scientists that clean air, water and even something as simple as hand washing reduced infection (Nightingale, 1860). Today, nurses continue to be uniquely positioned to address the health impacts of household sanitation, including exposure to household air pollution from cooking fires, which was estimated to cause 3.5 million deaths around the world in 2010 (Lim et al., Lancet, 2013). Most of the premature deaths from household air pollution are among women and young children, and it is estimated that 100,000 neonates die annually from this exposure. Most of these infants die from pneumonia, often compounded by low birth weight and/or prematurity. So what can nurses do to improve household health, including reducing exposure to household air pollution? Why are nurses important? First, nurses visit patients "in their homes (and) local communities... thus gaining firsthand knowledge.. . where environmental threats (are) often extreme" (Pope et al., 1995, pp. 2, 13). Nurses are also the largest group of health care providers in the world, and are often the initial and only point of contact for underserved, 
impoverished populations in need of health care. But where are the nurses who should be addressing this problem of household air pollution and its profound threat to health? Have nurses forgotten their roots grounded in environmental health? Many nurses have inadequate training and education to recognize and respond to the tremendous environmental threat of household air pollution. Addressing this problem goes beyond programs in schools of nursing, but also requires continuing education programs for nurses already in practice (Pope et al., 1995). It is not enough to initially train student nurses, the training should continue throughout the nursing career. It is imperative that nursing educators continue to develop educational programs that raise awareness about rural household health and hygiene, including household air pollution from cooking fires, which is a global environmental health issue. Currently nursing educators and students at the School of Nursing at USAT, are working to build ecotourism projects, latrines, stoves, and other hygiene projects. But more still needs to be done, and in some parts of the world, nothing is being done yet. 